\title{
Catcalling : Candaan, Pujian atau Pelecehan Seksual
}

\author{
Ida Ayu Adnyaswari Dewi ${ }^{1}$ \\ 1Program Studi Magister Kenotariatan, Fakultas Hukum Universitas Udayana, \\ E-mail: adnyaswaridewi@gmail.com
}

\begin{tabular}{l}
\hline Info Artikel \\
\hline Masuk: 22 April 2019 \\
Diterima: 19 Juni 2019 \\
Terbit: 21 Juli 2019 \\
Keywords: \\
Catcalling; Law; Legislation; \\
Public view; Sexual \\
harassment; Street harassment;
\end{tabular}

Kata kunci:

Catcalling; Hukum;

Pandangan masyarakat;

Pengaturan; Pelecehan seksual;

Pelecehan di jalan;

Corresponding Author:

Ida Ayu Adnyaswari Dewi,

E-mail:

adnyaswaridewi@gmail.com

DOI :

10.24843/AC.2019.v04.02.p.04

\begin{abstract}
The act of whistling, being called as "darling", "gek", "handsome" or "beautiful" and unwanted verbal comments are classified as "catcalling", which is included as a form of harassment. This harassment can be easily experienced by anyone in their daily lives, even today, it is still considered as something normal. Seeing this phenomenon, it is deemed necessary to study the "catcalling" regulation in the Indonesian legal system and the view of the community towards "catcalling" itself. The purpose of this journal is to find out the regulations and the views of the community toward "catcalling". The result that obtained in this study is the regulation of "catcalling" indirectly, already in Indonesian Law in the Article 281 of the Criminal Code, Article 351 of the Criminal Code, Article 9 of the Pornography Law, Article 35 of the Pornography Law and Article 86 paragraph (1) of the Employment Law, but with the differences in the use of the terms in the articles eventually, can limit the use of these articles. Based on the results of an online survey, most people said that "catcalling" is not a joke or praise, those who experience "catcalling" feel angry, disgusted and afraid when they experience it. The survey result shows that it is necessary to have a specific regulation to regulate "catcalling."
\end{abstract}

Abstrak
Tindakan bersiul, dipanggil dengan sebutan "sayang", "gek",
"ganteng" atau "cantik" dan komentar verbal yang tidak
diinginkan, tergolong kedalam "catcalling" yang termasuk
sebagai bentuk pelecehan. Pelecehan ini dengan sangat mudah
dapat dialami oleh siapapun dalam kehidupan sehari-harinya,
bahkan sampai saat ini hal tersebut masih dianggap sebagai suatu
hal yang biasa. Melihat fenomena ini, maka dirasa perlu untuk
dikaji pengaturan "catcalling" dalam sistem hukum Indonesia
dan pandangan masyarakat terhadap "catcalling" itu sendiri,
haruskah diadakan suatu aturan mengenai "catcalling". Tujuan
penulisan jurnal ini ialah untuk mengetahui tentang pengaturan
dan pandangan masyarakat terhadap "catcalling". Hasil yang
didapatkan dalam penelitian ini ialah aturan "catcalling" secara
tidak langsung sudah ada di dalam peraturan perundang-
undangan di Indonesia pada Pasal 281 KUHP, Pasal 351 KUHP,
Pasal 9 UU Pornografi, Pasal 35 UU Pornografi dan Pasal 86
ayat (1) UU Ketenagakerjaan, namun dengan adanya perbedaan
penggunaan istilah dalam setiap pasal mengakibatkan dibatasinya
penggunaan pasal-pasal tersebut. Berdasarkan hasil survei online
sebagian besar masyarakat menyebutkan bahwa "catcalling"
bukanlah suatu candaan atau pujian, mereka yang mengalami
"catcalling" merasa marah, jijik dan takut ketika mengalami




\section{Pendahuluan}

Setiap orang berhak atas rasa aman dan tentram serta perlindungan terhadap ancaman ketakutan, hal ini diatur dalam Pasal 30 Undang-Undang Nomor 39 Tahun 1999 tentang Hak Asasi Manusia (Undang-Undang HAM). Hak untuk memperoleh rasa aman ini dijamin oleh Konstitusi Republik Indonesia yaitu Undang-Undang Dasar Negara Republik Indonesia Tahun 1945 (UUD NRI 1945), Undang-Undang HAM, Deklarasi Universal Hak Asasi Manusia (DUHAM), dan kebijakan-kebijakan lainnya. Meski telah memiliki sejumlah kebijakan yang menjamin rasa aman, namun hal tersebut tidak dapat dirasakan dalam kehidupan sehari-hari. Tempat umum seperti sarana transportasi publik, sarana olahraga, supermarket, bahkan tempat yang seharusnya memberikan rasa aman seperti sekolah, tempat kerja dan tempat ibadah, sering menjadi tempat dimana ketidakamanan dapat dirasakan.

Siulan, dipanggil dengan sebutan "sayang", "gek", "ganteng" atau "cantik" oleh orang yang tidak dikenal, komentar yang tidak diinginkan, seperti "mau kemana cantik? mau ditemenin, nggak?", "jangan galak-galak nanti dicium ya!", diamati tubuhnya oleh orang asing hingga rabaan yang tidak diharapkan merupakan kejadian yang memunculkan rasa tidak aman, yang sering ditemui tapi luput dari perhatian karena dianggap sebagai sesuatu yang biasa. Rasa tidak aman ini biasa dialami sehari-hari, baik di Indonesia maupun di negara lain. Penelitian secara konsisten telah menunjukkan bahwa gangguan yang nampaknya kecil ini merupakan rutinitas dari negosisasi ruang publik dan ruang semi publik yang dialami sehari-hari, statistik menunjukkan bahwa sebanyak $90 \%$ perempuan pernah mengalami pelecehan di jalan setidaknya sekali dalam hidup mereka. ${ }^{1}$ Perbuatan yang menimbulkan rasa tidak aman ini, seperti yang di sebutkan diatas, dikategorikan sebagai street harassment. Street harassment merupakan tindakan-tindakan seperti bersiul, menatap atau melotot secara berkepanjangan, meraba-raba, mengikuti seseorang dan komentar verbal yang mengganggu. ${ }^{2}$ Menurut laporan yang berjudul "Unsafe and Harassed in Public: A National Street Harassment Report", street harassment atau pelecehan jalan diartikan merupakan suatu interaksi yang tidak diinginkan yang terjadi pada ruang publik yang melibatkan dua pihak atau lebih yang tidak saling mengetahui satu sama lain dan biasanya disebabkan oleh gender, orientasi seksual atau ekspresi gender, mengakibatkan korban merasa kesal, marah, malu ataupun takut. ${ }^{3}$ Street harassment, sering diidentifikasikan sebagai suatu pelecehan seksual di tempat umum yang sebagian besar korbannya adalah perempuan, namun tidak menutup kemungkinan

\footnotetext{
${ }^{1}$ Fileborn, B. (2016). Justice 2.0: Street Harassment Victims' Use Of Social Media And Online Activism As Sites Of Informal Justice. British Journal Of Criminology,57(6), 1482-1501. DOI: 10.1093/bjc/azw093, p. 1482.

${ }^{2}$ Fileborn, B., \& Vera-Gray, F. (2017). "I Want To Be Able To Walk The Street Without Fear": Transforming Justice For Street Harassment. Feminist Legal Studies, 25(2), 203-227. DOI : 10.1007/s10691-017-93503-3, p. 205.

${ }^{3}$ Stop Street Harassment. (2014). Unsafe and Harassed in Public Spaces: A National Street Harassment Report, Reston, Virginia, p. 5.
} 
laki-laki juga menjadi korban. Menurut Kearl, dari usia muda sebanyak $80 \%$ wanita di seluruh dunia menghadapi perhatian yang tidak diinginkan di tempat umum. ${ }^{4}$

Berdasarkan penelitian yang dilakukan oleh YouGov pada tahun 2014, Jakarta menduduki peringkat kelima sebagai kota dengan tingkat pelecehan verbal terhadap perempuan paling tinggi, khususnya di transportasi umum. ${ }^{5}$ Pada tahun 2016, ActionAid melakukan survei tentang street harassment di sejumlah negara. Mereka menemukan bahwa 75\% perempuan di London, 79\% perempuan yang tinggal di kotakota di India, 86\% di Thailand, dan 89\% di Brasil telah mengalami pelecehan atau kekerasan di depan umum. Menurut catatan tahunan Komisi Nasional Anti Kekerasan Terhadap Perempuan (Komnas Perempuan), di tahun 2017 terdapat 348.446 kasus kekerasan terhadap perempuan yang tercatat, $26 \%$ atau 3.528 kasus diantaranya terjadi di ruang publik. Data yang diperoleh Komnas Perempuan berdasarkan kuesioner, menunjukkan terjadinya peningkatan kasus kekerasan terhadap perempuan sebanyak 25\% dibandingkan dengan tahun 2016. Kasus kekerasan terhadap perempuan di ruang publik yang tercatat pada 2017, terdapat sebanyak 2.657 kasus merupakan kekerasan seksual yang terdiri dari pencabulan (911 kasus), pelecehan seksual (704 kasus), pemerkosaan (699 kasus) dan persetubuhan (343 kasus). Kenaikan jumlah tersebut tidak dapat disimpulkan bertambahnya kasus kekerasan terhadap perempuan, namun dapat juga diartikan bahwa semakin banyaknya korban yang berani dan sadar untuk melapor. Hal ini menunjukkan meningkatnya kepercayaan dan kebutuhan korban pada lembaga-lembaga pengada layanan. ${ }^{6}$

Beberapa tahun belakangan street harassment, menjadi suatu yang menjadi perhatian terutama di dunia maya karena korban yang mengalami pelecehan ini, merekam pengalaman mereka saat dilecehkan. Situs web seperti Holla Back!, Stop Street Harassment, Never Okay Project dan akun Instagram @dearcatcallers.id merupakan beberapa dari banyak platform yang menjembatani korban pelecehan untuk mendiskusikan pengalamannya dan memberitahukan pada publik tentang contohcontoh penelponan dan pelecehan yang dialaminya. Gerakan-gerakan yang melakukan penolakan terhadap street harassment serta peningkatan kepercayaan dari korban kepada lembaga pengada layanan tidak dibarengi dengan ketersediaan legal remedies bagi individu yang menjadi pelaku pelecehan ini. Menurut Heben, sebagaimana diungkapkan dalam tesis Coleen O'Leary, faktanya, sistem hukum kita telah secara umum menolak untuk mengakui bahwa street harassment ada. ${ }^{7}$

Menurut Logan, street harassment merupakan serangkaian praktek dengan tindakan seperti catcalling, menatap atau melotot berkepanjangan, meraba-raba, mengikuti seseorang dan komentar verbal yang mengganggu. ${ }^{8}$ Street harassment yang dilakukan

\footnotetext{
${ }^{4}$ Kearl, H. (2010). Stop Street Harassment: Making Public Places Safe and Welcoming For Women. ABC-CLIO, p.3.

5 Stop Street Harassment. "Statistics - The Prevalence of Street Harassment". Available from http://www.stopstreetharassment.org/resources/statistics/statistics-academic-studies/. (Diakses tanggal 15 Maret 2019).

6 Komnas Perempuan. Catatan Kererasan Terhadap Perempuan Tahun 2017. Available from https://www.komnasperempuan.go.id/file/pdf_file/2018/Publikasi/Catatan\%20Tahunan\%20Kekerasan \%20Terhadap\%20Perempuan\%202018.pdf. (Diakses tanggal 20 Maret 2019).

7 O'Leary, Coleen. (2016). Catcalling As A "Double Edged Sword": Midwestern Women. Their Experiences and The Implications Of Men's Catcalling Behaviors, Illinois State University, p. 2.

${ }^{8}$ Logan, L. S. (2015). Street Harassment: Current and Promising Avenues for Researchers and Activists. Sociology Compass, 9(3). DOI: https://doi.org/10.1111/soc4.12248, p. 198.
} 
dengan bersiul, memanggil dengan sebutan "sayang", "gek", "ganteng" atau "cantik" dan komentar verbal yang mengganggu oleh orang yang tidak dikenal merupakan tergolong ke dalam catcalling yang termasuk sebagai bentuk pelecehan di jalan, membuat komentar seksual pada orang yang sedang lewat, mengikuti mereka dan mencoba untuk terlibat pada percakapan atau meneriaki penghinaan rasial saat mereka di jalan. Tidak jarang perilaku ini meningkat menjadi berkedip, menguntit atau lebih buruk. Tindakan ini merupakan bagian dari pelecehan seksual verbal dan catcaller, pelaku yang melakukan catcalling, biasanya melakukan hal ini karena ingin mendapatkan perhatian dan berharap si perempuan akan merespon. Pelecehan seksual verbal oleh beberapa negara, seperti Perancis, Argentina, Portugal, Belgia dan Peru, telah ditanggapi secara serius karena berdampak besar pada kehidupan sosial manusia dan psikologis korban. Negara-negara tersebut menerapkan bukan hanya sanksi pidana tetapi juga sanksi denda kepada pelaku yang melakukan catcalling atau pelecehan seksual verbal.

Pelecehan dengan tendensi seksual di jalan merupakan peristiwa yang dianggap biasa dan seolah dibiarkan. Hal ini dapat kita lihat pada kisah seorang dokter yang bernama Falla Adinda mengalami catcalling di tempat kerjanya. Pada bulan September 2017, ia mengalami catcalling, ini bukan lah pertama kalinya ia mengalami hal ini, ia digoda dengan sebutan "hai, cantik", biasanya ketika mendapat catcalling ia akan mendatangi dan berbicara kepada pelaku, namun pada saat itu ia sudah tidak tahan dengan tindakan si pelaku sehingga memilih untuk pergi dan mendiamkan pelaku. Falla lalu melaporkan kejadian ini kepada polisi dan meminta polisi untuk menindak pelaku catcalling, alih-alih ditanggapi dan dibantu tapi Falla kemudian diremehkan dengan cara diperintahkan untuk pergi. Setelah mengalami penolakan oleh polisi pertama lalu Falla bertemu dengan polisi lain yang kebetulan sedang ada di sekitar kantornya. Polisi kedua ini berbeda dengan polisi sebelumnya, setelah mendengar cerita dari Falla, ia langsung merespon pengaduan dan mengajak bicara pelaku agar tidak melakukan catcalling lagi. Cerita Falla menjadi viral karena ada salah satu pihak kepolisian di Twitter yang merespons cerita ini dan polisi yang mengabaikan pengaduan Falla akhirnya meminta maaf. ${ }^{9}$ Falla merupakan salah seorang yang beruntung karena memiliki akses media sosial dan berani bicara, namun masih banyak perempuan di luar sana yang mengalami catcalling dan lebih memilih untuk diam dan pergi karena takut melawan. Tidak banyak yang berani memberi bantuan ataupun memberi pembelaan terhadap korban catcalling karena takut akan menjadi keributan.

Seiring dengan kemajuan jaman dan perkembangan teknologi informasi maka permasalahan terkait street harassment akan marak bermunculan, hal ini dikarenakan oleh semakin banyak korban yang berani untuk menceritakan hal ini ke publik, namun sangat disayangkan tidak diiringi dengan instrumen hukum yang jelas. Pentingnya aturan hukum yang jelas terhadap catcalling ini karena berbagai upaya yang dilakukan oleh korban untuk merespon catcalling, baik itu dengan cara menganggap bahwa yang dilakukan oleh pelaku merupakan suatu tindakan ramah tamah, mendiamkan pelaku atau melawan pelaku, korban tetap membayar mahal terhadap kondisi psikologinya sendiri. Mengacu pada permasalahan ini maka, perlu dikaji bagaimana pengaturan catcalling dalam sistem hukum Indonesia? dan bagaimana pandangan masyarakat

\footnotetext{
${ }^{9}$ Dharni, Arman. (2017). Dedi Mulyadi, Catcalling dan Ragam Pelecehan Perempuan. Available from https://tirto.id/dedi-mulyadi-catcalling-dan-ragam-pelecehan-perempuan-b6cC. (Diakses pada 9 April 2019).
} 
terhadap catcalling itu sendiri, haruskah diadakan suatu aturan mengenai street harassment khususnya catcalling?

Untuk menjamin originalitas dari jurnal ini serta untuk menganalisa dan memperkaya pembahasan penulisan jurnal, maka dilakukan perbandingan dengan beberapa penelitian sebelumnya yang berkaitan dengan pembahasan jurnal ini. Adapun penelitian-penelitian tersebut antara lain:

a. Jurnal yang berjudul "Justice, 2.0: Street Harassment Victims Use Of Social Media and Online Activism As Sites of Informal Justice", diteliti oleh Bianca FileBorn, pada tahun 2017 yang meneliti mengenai potensi media sosiak sebagai sarana untuk mendapatkan keadilan informal bagi korban pelecehan di jalan. Berdasarkan hasil penelitian jurnal ini ditemukan bahwa media sosial mampu berfungsi sebagai tempat bagi para korban untuk mendapatkan keadilan namun hanya keadilan yang terlaksana secara online.

b. Jurnal yang berjudul "My Name Is Not "Beautiuful," and, No, I Do Not Want To Smile: Paving The Path For Street Harassment Legislation In Illionois", diteliti oleh Amanda Roenius pada tahun 2016 yang meneliti mengenai pengaturan pelecehan di jalan di Illinois (negara bagian Amerika Serikat). Hasil yang ditunjukkan menurut jurnal ini ialah hak individual dan mobilitas tubuh masih terabaikan, namun hal ini dapat ditanggulangi dengan mengimplementasikan Safe Spaces Statute untuk melindungi hak-hak individu serta membuka jalan bagi negara bagian maupun negara lain untuk menyusun undang-undang yang serupa.

c. Penelitian yang berjudul "Catcalling as a "Double Edge Sword": Midwestern Women, Their Experinces, and the Implications of Mens's Catcalling Behasviours", diteliti oleh Coleen O'Leary, pada tahun 2016 yang meneliti mengenai sudut pandang perempuan-perempuan Midwestern's USA terhadap catcalling melalui interview mendalam mengenai pengalaman dan persepsinya mengenai catcalling. Kesimpulan dari penelitian ini menunjukkan bahwa perempuanperempuan tersebut tidak pernah menganggap bahwa catcalling sebagai suatu pujian, sebaliknya para pria menganggap bahwa komentar yang mereka berikan merupakan pujian. Berdasarkan data yang diperoleh, perempuanperempuan ini merasa bahwa pengalaman dan persepsi mereka mengenai catcalling diabaikan oleh laki-laki dan masyarakat karena catcalling masih dianggap sebagai suatu pujian.

\section{Metode Penelitian}

Data pada jurnal ini berasal dari tanggapan koresponden terhadap pertanyaan survei terbuka. Pertanyaan yang diberikan berkaitan dengan pemahaman hukum, kebutuhan dan respon yang berhubungan dengan catcalling. Survei ini dilakukan dengan cara survei online, pada April 2019, menggunakan sarana google form yang disebarkan melalui jejaring sosial pada masyarakat yang bertempat tinggal di Denpasar, Badung dan Gianyar. Topik pertanyaan meliputi demografi, pemahaman mengenai catcalling, pengalaman mereka tentang catcalling, keturutsertaan dalam pengalaman catcalling, dan respon terhadap kebutuhan akan adanya suatu aturan. Tanggapan untuk sebagian besar pertanyaan bersifat opsional sedangkan untuk 2 pertanyaan bersifat penjelasan. Karena survei yang dilakukan bersifat anonim, maka tidak mungkin untuk dilakukan penindaklanjutan terhadap tanggapan koresponden. Data yang diperoleh melalui survei ini kemudian diolah secara kualitatif dan hasilnya disajikan secara deskriptif analisis. Data primer yang digunakan dalam penelitian ini berupa hasil survei, maka 
dapat diketahui bahwa jurnal ini menggunakan metode penelitian empiris yang dalam penelitiannya menggunakan keadaan sosial masyarakat sebagai fokus penelitiannya. Sebelum meneliti data primer melalui survey telah dilakukan penelitian terhadap data sekunder yang diperoleh dari bahan-bahan kepustakaan yang bersumber pada bahan hukum primer.

\section{Hasil dan Pembahasan}

\subsection{Pengaturan Catcalling dalam Sistem Hukum Indonesia}

Pelecehan seksual adalah segala tingkah laku seksual yang tidak diinginkan, permintaan untuk melakukan perbuatan seksual, baik secara lisan atau fisik, seperti isyarat yang bersifat seksual atau perilaku lain apapun yang bersifat seksual, yang menjadikan seseorang merasa tersinggung, dipermalukan dan/atau terintimidasi. ${ }^{10}$ Mengacu pada pengertian sexual harassment oleh Martin Eskenazi dan David Gallen, Istiana Hermawati dan Achmad Sofian mengartikan pelecehan seksual sebagai diberikannya suatu tuntutan seksual yang tidak dinginkan atau diciptakannya suatu lingkungan yang ofensif secara seksual, dalam bahasa yang sederhana disebut juga dengan perhatian yang tidak diinginkan atau unwelcome attention. ${ }^{11}$ Pelecehan seksual pada umumnya dikelompokkan menjadi 3 komponen utama, yaitu: pemaksaan seksual, pelecehan gender dan perhatian seksual yang tidak diharapkan. ${ }^{12}$ Pemaksaan seksual ini diartikan sebagai permintaan secara langsung atau persyaratan untuk melakukan tindakan seksual sebagai imbalan terkait pekerjaan atau sekolah, sedangkan pelecehan gender merupakan degradasi perempuan yang dilakukan secara bergrup seperti membuat lelucon tentang perempuan sebagai objek seks atau memposting gambar objek perempuan sebagai objek seks. Terakhir, perhatian seksual yang tidak diinginkan merupakan degradasi perempuan yang dilakukan secara individual, seperti memperlakukan perempuan sebagai objek seks dengan mengirimkan email atau pesan pribadi yang tidak pantas, meraba atau menyentuh secara tidak pantas, dan melirik dengan maksud seksual.

Pengertian pelecehan seksual diatas dapat dilihat terdapat unsur penting, yaitu adanya rasa ketidakinginan atau penolakan pada apapun bentuk-bentuk tingkah laku atau perilaku yang bersifat seksual. Pelecehan seksual mengenal beberapa bentuk yang dikelompokkan ke dalam lima bentuk pelecehan, yaitu pelecehan fisik; pelecehan lisan; pelecehan isyarat; pelecehan tertulis atau gambar; dan pelecehan psikologis atau emosional. Perbuatan-perbuatan yang dapat dikategorikan pelecehan fisik adalah perhatian yang tidak diinginkan yang disampaikan dengan cara bersentuhan secara fisik yang mengarah ke perbuatan seksual, seperti rabaan yang tidak diinginkan ataupun pandangan penuh pada bagian badan. Panggilan, lelucon maupun komentar yang tidak diinginkan serta bernada seksual tentang pribadi atau bagian tubuh atau penampilan seseorang dikategorikan sebagai suatu pelecehan lisan atau verbal. Tindakan berupa bahasa tubuh, gerakan tubuh bernada seksual, kerlingan yang dilakukan berulang-ulang kali, isyarat dengan jari dan menjilat bibir dengan maksud seksual, dikategorikan ke dalam pelecehan seksual isyarat. Pelecehan tertulis atau

\footnotetext{
${ }^{10}$ Kementerian Tenaga Kerja dan Transmigrasi. (2011). Pedoman Pencegahan Pelecehan Seksual di Tempat Kerja. Indonesia, h. 6.

${ }^{11}$ Hermawati, I., \& Sofian, A. (2018). Kekerasan Seksual oleh Anak Terhadap Anak. Jurnal Penelitian Kesejahteraan Sosial, 17(1), ISSN: 2528-0403, h. 4

12 Fairchild, K., \& Rudman, L. A. (2008). Everyday Stranger Harassment And Women's Objectification. Social Justice Research, 21(3), 338-357. DOI: 10.1007/s11211-008-0073-0, p. 340.
} 
gambar merupakan pelecehan dengan cara mempertontonkan pornografi, seperti foto, video, screensaver, poster seksual, atau pelecehan lewat email dan sarana komunikasi lainnya. Permintaan-permintaan dan ajakan-ajakan yang terus menerus dan tidak diinginkan, ajakan kencan yang tidak diharapkan serta penghinaan atau celaan yang bersifat seksual merupakan suatu pelecehan psikologis atau emosional.

Merujuk pengertian tentang pelecehan seksual ini, maka catcalling dapat dikategorikan sebagai suatu tindak pelecehan seksual secara verbal, karena catcalling adalah kondisi ketika perhatian yang tidak diinginkan diberikan kepada seseorang oleh orang lain dengan cara bersiul atau membuat komentar yang tidak pantas sebagai tanggapan ketertarikan seksual kepada penerima perhatian. ${ }^{13}$ Dalam jurnal Livia Jayanti Putri dan I Ketut Suardita, dikatakan bahwa catcalling dapat dikatakan sebagai suatu perbuatan pidana karena telah memenuhi unsur-unsur tindak pidana menurut Prof. Simons, yang antara lain adanya suatu perbuatan yang dilakukan oleh manusia, dapat diancam pidana, melawan hukum, dilakukan dengan kesalahan, dan orang yang melakukan mampu bertanggung jawab. ${ }^{14}$ Istilah catcalling di Indonesia masih jarang di dengar oleh masyarakat luas, pada umumnya hal ini dapat dikenali melalui perbuatan bersiul, berteriak atau memberi komentar seksual kepada orang yang lewat. Catcalling membuat banyak orang yang dilecehkan merasa tidak aman berada di ruang publik. Para korban di sini tidak mendapatkan rasa hormat dari pelaku. Pelaku menggunakan tindakan ini guna mendapatkan kekuatan dan kontrol psikologis dan emosional dari korban. ${ }^{15} \mathrm{Hal}$ ini mempengaruhi kemana mereka akan pergi, kapan, dengan siapa dan bagaimana mereka berpakaian. Ini juga dapat mempengaruhi hobi dan kebiasaan korban, bahkan dapat menyebabkan beberapa orang untuk pindah atau keluar dari pekerjaan karena pelecehan di sekitarnya.

Dalam Kitab Undang-Undang Hukum Pidana (KUHP) di Indonesia tidak mengenal istilah pelecehan seksual, hal ini karena dalam KUHP Bab XIV tentang Kejahatan Terhadap Kesusilaan yang didalamnya terdapat istilah perbuatan cabul yang diatur dalam Pasal 289 sampai dengan Pasal 296 KUHP. Menurut Ratna Batari Munti dengan mengutip R. Soesilo, perbuatan cabul diartikan sebagai perbuatan yang melanggar rasa kesusilaan atau perbuatan lain yang keji dan semua dalam lingkungan nafsu birahi kelamin, misalnya cium-ciuman, meraba-raba anggota kemaluan, meraba-raba payudara dan sebagainya. ${ }^{16}$ Perbuatan cabul disini memiliki lingkup yang kecil, karena hanya mengatur mengenai perbuatan seperti perzinahan, pemerkosaan dan perdagangan orang.

Pasal 281 KUHP mengatur bahwa seseorang dapat diancam pidana atau denda, apabila dengan sengaja dan terbuka melanggar kesusilaan baik di depan umum atau di depan orang lain. Kesusilaan yang dimaksud dalam pasal ini memiliki arti yang sama dengan perbuatan cabul, yaitu perasaan malu yang berhubungan dengan nafsu kelamin, misalnya bersetubuh, meraba buah dada orang perempuan, meraba alat kelamin, memperlihatkan alat kelamin. Terkait dengan pelanggaran kesusilaan dengan

\footnotetext{
${ }^{13}$ Baja, Nico L. (2017). “Witwiw, Hi Miss!” Bastos Ba O Hindi: Catcalling Between Men and Women in Imus City, Cavite. Cavite State University, p. 11.

${ }^{14}$ Putri, L. J., \& Suardita, I. K. (2019). Tinjauan Yuridis Terhadap Perbuatan Catcalling (Pelecehan Verbal) Di Indonesia. Kertha Wicara, Retrieved from https://ojs.unud.ac.id/index.php/kerthawicara/article/view/47598, h. 5-6.

${ }^{15}$ Ibid., p. 14.

16 Munti, Ratna Batara. (2001). Kekerasan Seksual: Mitos dan Realitas. Available at: https://www.hukumonline.com/berita/baca/hol2472/kekerasan-seksual-mitos-dan-realitas. (Diakses tanggal 9 April 2019)
} 
perkataan, terdapat perbedaan pendapat mengenai penggunaan Pasal 281 KUHP, Prof. Dr. D. Simons, dalam buku R. Soesilo, menentang adanya kemungkinan pelanggaran terhadap kesusilaan dengan perkataan, namun jika memang benar maka orang tersebut dapat dikenakan Pasal 315 KUHP yang mengatur tentang penghinaan yang dilakukan dengan sengaja yang tidak bersifat pencemaran terhadap korban yang dihina. ${ }^{17}$

Hal lain diungkapkan oleh Mr. W.F.L. Buschkens, dalam buku R. Soesilo, ia mengatakan bahwa penghinaan merupakan hal yang merusak kesusilaan dalam pengertian umum sedangkan pernyataan yang meliputi soal nafsu kelamin adalah pengertian khusus dari merusak kesusilaan. ${ }^{18}$ Ketentuan dalam Pasal 63 ayat (2) KUHP menyatakan apabila suatu perbuatan masuk dalam suatu pidana yang umum, namun memiliki pengaturan pidana yang khusus maka yang digunakan adalah aturan pidana yang khusus tersebut. Berdasarkan bunyi Pasal 63 ayat (2) KUHP maka lebih tepat menggunakan Pasal 281 KUHP dari pada Pasal 315 KUHP.

Selain dalam KUHP, aturan pelecehan seksual verbal ditemukan dalam UndangUndang Nomor 44 Tahun 2008 tentang Pornografi (UU Pornografi). Dalam UU tersebut pornografi diartikan sebagai segala bentuk media dan/atau pertunjukkan di muka umum yang berkaitan dengan perbuatan cabul atau eksploitasi seksual yang melanggar norma-norma yang ada di masyarakat. Pengertian pornografi ini mengandung makna bahwa catcalling dapat dikatakan sebagai suatu hal yang bermuatan pornografi, karena memenuhi unsur bunyi, gerak tubuh, suara dan pesan yang cabul. Pasal 9 UU Pornografi melarang menjadikan orang lain sebagai objek atau model yang mengandung konten pornografi, apabila hal ini dilakukan, maka sesuai dengan Pasal 35 UU Pornografi, pelaku yang melakukan perbuatan yang dirumuskan dalam Pasal 9 UU Pornografi dapat dikenakan sanksi pidana dan pidana denda.

Meski tidak secara eksplisit mengatur tentang pelecehan seksual secara verbal, Undang-Undang Republik Indonesia Nomor 13 Tahun 2003 tentang Ketenagakerjaan (UU Ketenagakerjaan) memberikan perlindungan terhadap masalah moral dan kesusilaan bagi tenaga kerjanya dan hal ini diatur dalam Pasal 86 ayat (1) UU tersebut. Undang-undang Ketenagakerjaan tidak mengatur pengertian dari kesusilaan, oleh karena itu makna kata kesusilaan yang dapat digunakan adalah makna yang termuat dalam KUHP, maka jika catcalling dilakukan di tempat kerja maka seharusnya tenaga kerjanya memperoleh perlindungan akan hal tersebut.

Suatu aturan khusus mengenai catcalling ada dalam Rancangan Undang-Undang Republik Indonesia tentang Penghapusan Kekerasan Seksual (RUU PKS). Pasal dalam RUU PKS ini tidak memberikan arti khusus mengenai apa itu pelecehan seksual, namun dalam Pasal 11 ayat (1), pelecehan seksual termasuk ke dalam kekerasan seksual. Kekerasan seksual dalam UU ini diartikan sebagai segala perbuatan atau ucapan yang dilakukan dengan hasrat seksual maupun reproduksi bertentangan dengan kehendak seseorang, dimotivasi karena adanya ketimpangan relasi atau gender, yang mengakibatkan trauma maupun penderitaan secara fisik, psikis, seksual, kerugian secara ekonomi, sosial, budaya dan/atau politik. Pengertian khusus terhadap pelecehan seksual terdapat dalam naskah akademik RUU PKS. Pelecehan seksual diartikan sebagai segala perbuatan baik fisik maupun non-fisik yang menjadikan organ seksual atau seksualitas korban sebagai sasarannya, prakteknya dilakukan dengan

\footnotetext{
${ }^{17}$ Soesilo, R. (1986). Kitab Undang-Undang Hukum Pidana (KUHP) serta Komentar-Komentarnya Lengkap Pasal Demi Pasal. Bogor: Politeia, h. 204.

${ }^{18}$ Ibid., h. 205.
} 
panggilan-panggilan yang tidak diinginkan, gerakan atau isyarat yang menunjukkan secara terang-terangan adanya keinginan seksual yang bersifat seksual sehingga mengakibatkan rasa tidak nyaman, tersinggung, merasa direndahkan martabatnya, dan mungkin sampai menyebabkan masalah kesehatan dan keselamatan. ${ }^{19}$ Terkait dengan catcalling, dalam UU ini ketentuannya diatur dalam Pasal 12 yang pada intinya mengatur tentang perbuatan, gerakan atau isyarat yang bernuansa seksual, ajakan melakukan hubungan seksual, mempertunjukkan materi pornografi, mempertunjukkan alat kelamin, merekam atau memfoto secara diam-diam tubuh orang. Terhadap orang-orang yang melakukan perbuatan sebagaimana diatur dalam UU ini maka akan dikenakan pidana pelecehan seksual yang terdapat dalam Pasal 113 UU tersebut, yang meliputi rehabilitasi khusus, pidana tambahan kerja sosial dan pengumuman putusan hakim.

Catcalling pada dasarnya merupakan pelecehan seksual verbal yang pelakunya memberikan perhatian yang tidak diinginkan kepada orang lain, dengan cara memberikan siulan, komentar dan ucapan yang bernuansa seksual dan tindakan bernuansa seksual lainnya yang tidak berkenaan dengan fisik korban. Memfokuskan terhadap kata perbuatan yang tidak diinginkan, maka dapat dilihat bahwa catcalling merupakan delik aduan, karena bisa saja tindakan catcalling menurut budaya dan sopan santun wilayah setempat merupakan hal yang wajar. Menjadi masalah ketika tindakan catcalling ini tidak dikehendaki oleh orang yang menjadi korban catcalling, sehingga dapat dikategorikan sebagai suatu pelecehan seksual.

Uraian diatas menunjukkan bahwa sesungguhnya tindakan catcalling atau pelecehan seksual secara verbal memiliki aturan dalam hukum positif di Indonesia, hanya saja masih ada pro kontra terhadap pengenaan pasal yang dapat digunakan guna mempidana pelaku. Sampai saat ini belum ada suatu putusan pengadilan atau doktrin oleh ahli hukum Indonesia yang dapat memberikan titik terang terhadap pemilihan pasal yang dapat digunakan untuk mempidanakan pelaku. RUU PKS yang secara khusus mengatur mengenai catcalling pun belum memperoleh kepastian kapan akan disahkan, karena sampai saat ini RUU PKS mengalami beberapa miskonsepsi di masyarakat.

\subsection{Pandangan Masyarakat terhadap Pengadaan Suatu Aturan Mengenai Catcalling}

Beberapa orang masih berpendapat bahwa melakukan catcalling bukanlah suatu pelecehan, melainkan komentar dengan maksud bercanda atau hanya bermaksud iseng. Pendapat demikian sangat bertolak belakang dengan kenyataan karena gerakangerakan anti catcalling bermunculan di seluruh penjuru dunia dan banyak korban mulai menceritakan hal tersebut, baik di media sosial ataupun di dunia nyata, dengan luapan emosi bercampur rasa takut. Demi menunjang pembahasan jurnal ini, telah dilakukan survei online yang dilakukan guna mengetahui pandangan masyarakat tentang catcalling. Survei ini di sebar melalui jejaring sosial seperti Whatsapp, Line dan Instagram.

Survei yang dilakukan pada bulan April 2019 ini diperoleh sebanyak 150 koresponden, yang terdiri dari 61,3\% (92 orang) perempuan dan 38,7\% (58 orang) laki-laki. Survei

19 Dewan Perwakilan Rakyat Repubulik Indonesia. (2017). Naskah Akademik Rancangan UndangUndang Tentang Penghapusan Kekerasan Seksual. Available at: http://www.dpr.go.id/doksileg/proses1/RJ1-20170307-091105-5895.pdf, h. 24. (Diakses tanggal 9 April 2019). 
diisi oleh 25,3\% (38 orang) masyarakat berumur $17-20$ tahun, 51\% (78 orang) masyarakat berumur 21-25 tahun, 20\% (30 orang) masyarakat berumur 25-30 tahun, 2\% (3 orang) masyarakat berumur 31-40 tahun, 0\% masyarakat berumur 41-50 tahun dan $0,7 \%$ (1 orang) masyarakat berumur 50 tahun keatas. Sebanyak 60,7\% (91 orang) bertempat tinggal di Denpasar, 11,3\% (17 orang) bertempat tinggal di Badung dan 28\% (42 orang) bertempat tinggal di Gianyar. Hasil survei menunjukkan, terdapat 92\% (138 orang) koresponden yang pernah mengalami dan melihat kejadian catcalling. Dalam survei disebutkan ada 4 bentuk catcalling yaitu komentar verbal, membunyikan klakson, siulan/suara kecupan dan lirikan/pandangan yang tidak mengenakkan. Bentuk pelecehan berupa siulan atau suara kecupan merupakan bentuk pelecehan yang paling banyak ditemui, kemudian pelecehan dengan komentar yang tidak diinginkan berada di posisi kedua terbanyak ditemui di masyarakat, selanjutnya lirikan atau pandangan yang tidak mengenakan menempati posisi ketiga dan membunyikan klakson berada di posisi ke empat.

Catcalling cenderung memicu bahaya seperti trauma psikologis dan emosi seperti ketakutan, karena perempuan yang di hina secara publik mengalami kerugian psikologis seperti perasaan terdegradasi, malu dan tidak berdaya. ${ }^{20}$ Meski sering mengalami catcalling dalam kehidupan sehari-harinya, nyatanya dari hasil survei terdapat $41,1 \%$ orang yang ditanggapi secara serius ceritanya ketika mengalami catcalling dan tak sedikit yang cenderung dikomentari masalah cara berpakaiannya ketika bercerita mengalami catcalling. Sebagian besar mengatakan bahwa catcalling bukanlah pujian maupun candaan, hal ini disepakati oleh 80\% (121 orang) koresponden, sedangkan 19,3\% (29 orang) mengatakan bahwa catcalling merupakan pujian atau candaan. Ketika ditanya, "bagaimana perasaan anda saat melihat/mengalami catcalling?" sebagian besar koresponden berbagi perasaaan yang sama, yaitu marah, terganggu dan takut. Seorang koresponden, laki-laki, dengan rentang usia 25-30 tahun, bertempat tinggal di Denpasar, mengatakan bahwa ia tidak menyukai tindakan catcalling, karena jika melihat seorang wanita di ganggu itu merupakan prilaku yang tidak pantas. Hal serupa juga disampaikan oleh koresponden perempuan, rentang usia 17-20 tahun, bertempat tinggal di Gianyar, ia mengatakan bahwa ketika ia menjadi korban, ia merasa sangat dilecehkan. Ia selanjutnya menyatakan bahwa hal tersebut kembali lagi pada kesadaran pelaku mengenai catcalling itu sendiri, karena sama seperti anak kecil yang tidak mengetahui bahwa itu salah, maka ia tetap akan melakukannya, pelaku cenderung tidak mengetahui tindakan catcalling itu merupakan pelecehan, bukan hanya pelaku tapi banyak korban yang tidak tahu, oleh karenanya perlunya edukasi yang luas agar lebih banyak orang yang tahu dan mengerti. Meskipun sebagian besar koresponden tidak senang terhadap kejadian catcalling, sangat disayangkan masih ada yang berpendapat catcalling merupakan sesuatu yang biasa saja dan hanya candaan.

Menurut 11 th Principle: Consent!, suatu organisasi non-profit yang memiliki perhatian khusus terhadap masalah hubungan non-konsensual, catcalling merupakan tindakan yang termasuk dalam rape culture pyramid dan menempati tingkatan terbawah dalam piramida tersebut. ${ }^{21}$ Selain catcalling pada tingkatan terbawah dari piramida ini

\footnotetext{
${ }^{20}$ Chhun, B. (2010). Catcalls: Protected Speech or Fighting Words. T. Jefferson L. Rev., 33, ISSN: 10905278, p. 290.

$2111^{\text {th }}$ Principle: Consent!. (tanpa tahun). Rape Culture Pyramid. Available at: https://www.11thprincipleconsent.org/consent-propaganda/rape-culture-pyramid/. (Diakses pada tanggal 15 April 2019).
} 
termasuk juga sikap seksis, candaan tentang perkosaan, sentuhan yang tidak diinginkan dan stalking (menguntit), yang dalam kehidupan sehari-hari hal tersebut dianggap normal atau mengalami normalisasi dari kebanyakan orang. Sedangkan tindakan pemerkosaan, drugging (memberi narkoba pada korban), penganiayaan, stealhing (melepaskan kondom secara diam-diam) dan sabotase kontrasepsi termasuk ke dalam tingkatan tertinggi dalam rape culture pyramid, yang termasuk ke dalam kejahatan. Jika penormalisasian masih terjadi terhadap tindakan-tindakan yang termasuk ke dalam tingkatan terbawah rape culture pyramid maka sampai kapanpun perempuan tidak akan memperoleh rasa aman, hal ini disebabkan karena tubuh perempuan akan selalu dijadikan sebagai objek seksual.

Kehadiran hukum di masyarakat diharapkan mampu mengatasi konflik kepentingan yang timbul akibat interaksi antar warga negaranya. Dengan adanya hukum maka diharapkan hukum dapat mengontrol tindakan yang meresahkan yang ada di masyarakat. Menurut Hugo Sinzheimer, dalam Achmad Ali dan Wiwie Heryani, dengan adanya kesenjangan antara keadaan, peristiwa serta hubungan dalam masyarakat, perubahan hukum akan senantiasa diperlukan. ${ }^{22}$ Menurut Supanto, keberadaan suatu hukum, khususnya hukum pidana, berfungsi untuk menciptakan ketertiban dan keamanan masyarakat, serta menimbulkan daya preventif untuk tidak dilakukan kejahatan. ${ }^{23}$ Terkait dengan tindakan catcalling ini sebaiknya hukum hadir untuk memberikan batasan terhadap perilaku tersebut dan juga sebagai suatu tindakan preventif. Hadirnya suatu aturan mengenai catcalling dirasa tepat karena melihat berbagai gerakan anti catcalling yang ada di masyarakat, yang selama ini membantu menyebarkan kesadaran terhadap publik dan mengedukasi pentingnya rasa aman di ruang publik.

Sebanyak 125 orang atau 83,3\% koresponden yang mengisi survei menyatakan perlu adanya suatu aturan terhadap tindakan catcalling ini, sedangkan 16,7\% nya mengatakan tidak perlu ada aturan terhadap catcalling. Sebagian besar yang mengatakan tidak perlu ada suatu aturan khusus terhadap catcalling berpendapat bahwa dengan adanya aturan tersebut bisa saja mengkriminalisasi orang yang melakukan catcalling dengan maksud bercanda, seharusnya korban bisa mengatasi sendiri dengan mengatur cara berpakaian serta catcalling merupakan naluri laki-laki.

Etika dan norma kesopanan dianggap dapat mengurangi tindakan catcalling ini. Salah satu koresponden mengatakan semua tergantung perempuan, jika tidak suka maka tidak perlu merespon tindakan catcalling tersebut, aturan tidak perlu dibuat karena negara tidak perlu mencampuri hal-hal seperti ini, karena ini merupakan masalah etika dan etika sudah diajarkan sejak sekolah dasar hingga perguruan tinggi. Hanya saja sampai saat ini tampaknya belum relevan untuk mengatakan etika dan norma kesopanan mampu mengurangi tindakan ini, tidak sedikit anak-anak yang melakukan catcalling terhadap orang yang jauh lebih tua dan ketika ditanggapi yang dilakukan oleh anak-anak itu adalah lari atau mengejek korban. Darimana anak-anak ini belajar melakukan catcalling? Penelitian mengatakan anak kecil suka mencontoh orang dewasa, mereka menganggap apa yang dilakukan oleh orang dewasa itu keren. Catcalling yang dilakukan oleh orang dewasa dan dianggap sebagai sesuatu yang wajar mempengaruhi kelakuan anak-anak, hal ini disebabkan karena diantara orang dewasa

\footnotetext{
22 Ibid., h. 205.

${ }^{23}$ Supanto, S. (2004). Pelecehan Seksual Sebagai Kekerasan Gender: Antisipasi Hukum Pidana. Mimbar: Jurnal Sosial dan Pembangunan, 20(3), 288-310, DOI: https://doi.org/10.29313/mimbar.v20i3.371, h. 289.
} 
sendiri kurang adanya persamaan opini bahwa melakukan "pujian" terhadap orang asing merupakan hal yang bertentangan dengan etika dan norma kesopanan. Tanpa pendampingan yang kurang memadai dan kurangnya persamaan opini mengenai catcalling ini maka sampai kapan pun catcalling tidak akan menemukan titik terang.

Sejarawan menemukan bahwa pelecehan publik sudah menjadi bahan diskusi pada koran-koran dan jurnal perempuan setidaknya sejak 1800an. ${ }^{24}$ Hingga saat ini aturan maupun putusan pengadilan mengenai pelecehan di Indonesia masih sangat jarang ditemukan. Perlunya aturan terhadap pelecehan seksual khususnya catcalling disampaikan oleh salah satu koresponden dengan mengatakan bahwa sangat perlu adanya aturan hukum yang tegas mengenai perbuatan catcalling karena korbannya adalah kebanyakan perempuan yang tentu saja perlu mendapatkan perlindungan secara hukum (Perempuan, 17-20 tahun, Badung). Pendapat lainnya mengatakan bahwa aturan catcalling perlu ada aturannya, karena tindakan yang dianggap remeh ini dapat menyakiti seseorang secara psikologis (Perempuan, 17-20 tahun, Gianyar). Lakilaki, umur berkisar 25-30 tahun, bertempat tinggal di Badung, mengatakan bahwa aturan terhadap catcalling perlu diadakan hanya saja perlu diperjelas sebatas mana aturan itu berlaku karena apabila hanya diartikan seperti arti katanya saja dapat menimbulkan banyak makna, bisa saja pelaku melakukan hanya untuk bercandaan.

Pengadaan aturan mengenai catcalling bukan hanya semata-mata untuk melindungi kepentingan korban maupun mengenai kesetaraan gender namun lebih kepada kewajiban negara untuk memberi rasa aman pada rakyatnya dengan membuat suatu pemahaman tentang suatu perbuatan. Dengan adanya aturan mengenai catcalling atau pelecehan verbal ini maka diharapkan akan muncul suatu pemahaman baru di masyarakat tentang catcalling atau pelecehan verbal itu sendiri. Sebagaimana dikatakan salah satu koresponden, perempuan, umur berkisar 21-25 tahun, bertempat tinggal di Denpasar, yang mengatakan bahwa rasa aman dan nyaman warga negara merupakan kewajiban negara, oleh karenanya perlu diadakan suatu aturan yang setidaknya mampu untuk memberikan rasa aman bagi setiap warga negara. Selain perlu adanya aturan, adanya sosialisasi terhadap masyarakat luas (laki-laki, 21-25 tahun, Denpasar). Catcalling merupakan pelecehan seksual yang dianggap sepele di masyarakat, namun untuk merubah pola pikir masyarakat yang sudah ada sejak ratusan tahun yang lalu bukanlah perkara yang mudah, diperlukan suatu kekuatan yang kuat untuk merubah pola pikir tersebut, jangan sampai pelecehan seksual secara verbal ini menjadi akar pelecehan seksual lainnya yang dapat berujung pada kekerasan seksual. Meskipun aturan mengenai catcalling nantinya akan ada, tapi belum tentu semua pelaku dapat dijatuhi hukuman, karena catcalling atau pelecehan seksual itu sendiri merupakan tindak pidana yang termasuk ke dalam delik aduan, karena unsur terpenting dari pelecehan seksual ialah unwelcome attention, sehingga bisa saja karena kebiasaan dan norma korban menganggap hal ini adalah sesuatu yang biasa dan bukan merupakan sesuatu yang tidak diinginkan. Pelecehan seksual tidak boleh didiamkan sebagai kejahatan yang tersembunyi (hidden crime), oleh karena itu aturan yang mengatur tentang pelecehan seksual harus segera disahkan. Aturan mengenai pelecehan seksual bukan lah hal baru. Kriminalisasi terhadap pelecehan seksual di negara-negara lain diatur dalam suatu aturan yang terpisah dengan tindak pidana kesusilaan biasa dan sanksinya pun beragam mulai dari sanksi pidana hingga sanksi administratif. Meratifikasi Konvensi mengenai Penghapusan Segala Bentuk Diskriminatif terhadap

\footnotetext{
${ }^{24}$ Stop Street Harassment., Op.cit., p. 7.
} 
Wanita menjadi alasan yang cukup kuat bagi Indonesia untuk mengesahkan dan menegakkan aturan yang berkaitan dengan pelecehan seksual.

\section{Kesimpulan}

Pengaturan terhadap tindakan catcalling secara tidak langsung di atur dalam Pasal 281 yang mengatur tentang perbuatan cabul dan Pasal 315 KUHP yang mengatur tentang penghinaan, selain itu pengaturan lain juga ditemukan dalam Pasal 9 dan Pasal 35 UU Pornografi. Perlindungan bagi individu dari catcalling diatur secara implisit dalam Pasal 86 ayat (1) UU Ketenagakerjaan. Meski aturan yang secara tidak langsung mengatur mengenai catcalling telah ada namun dengan adanya perbedaan penggunaan istilah dalam pasal yang pada akhirnya dapat membatasi penggunaan pasal-pasal tersebut terhadap kasus pelecehan seksual, khususnya catcalling. Pelecehan seksual, khususnya catcalling diatur secara khusus dalam RUU PKS, khususnya dalam Pasal 11, Pasal 12 dan Pasal 113. Meski RUU ini sudah mengatur mengenai catcalling, namun sampai saat ini RUU PKS masih mengalami polemik di masyarakat dan belum ada kejelasan kapan akan diundangkan.

Berdasarkan hasil survei online yang dilakukan diperoleh sebanyak 83,3\% koresponden merasa perlu ada aturan mengenai pelecehan seksual, khususnya catcalling. Sebagian besar koresponden merasa dengan adanya aturan maka masyarakat akan merasa aman dan terlindungi. Keberadaan aturan mengenai catcalling dirasa penting karena dapat memberikan suatu pandangan di masyarakat bahwa hal tersebut merupakan hal yang dilarang baik dari segi norma yang ada di masyarakat maupun hukum.

Ucapan terima Kasih (Acknowledgments)

Ucapan terima kasih ini saya sampaikan kepada 150 koresponden yang mau untuk meluangkan waktunya untuk mengisi survei sehingga penelitian ini dapat diselesaikan dengan baik.

\section{Daftar Pustaka}

Buku

Fajar, M., \& Achmad, Y. (2010). Dualisme Penelitian Hukum Normatif dan Empiris, Yogyakarta: Pustaka Pelajar.

Kearl, H. (2010). Stop Street Harassment: Making Public Places Safe and Welcoming For Women. ABC-CLIO.

Kementerian Tenaga Kerja dan Transmigrasi. (2011). Pedoman Pencegahan Pelecehan Seksual di Tempat Kerja. Indonesia.

Soesilo, R. (1986). Kitab Undang-Undang Hukum Pidana (KUHP) serta KomentarKomentarnya Lengkap Pasal Demi Pasal. Bogor: Politeia.

Stop Street Harassment. (2014). Unsafe and Harassed in Public Spaces: A National Street Harassment Report, Reston, Virginia.

\section{Jurnal}

Chhun, B. (2010). Catcalls: Protected Speech or Fighting Words. T. Jefferson L. Rev., 33, ISSN: 1090-5278.

Fairchild, K., \& Rudman, L. A. (2008). Everyday Stranger Harassment And Women's Objectification. Social Justice Research, 21(3), 338-357. DOI: 10.1007/s11211-0080073-0. 
Fileborn, B. (2016). Justice 2.0: Street Harassment Victims' Use Of Social Media And Online Activism As Sites Of Informal Justice. British Journal Of Criminology, 57(6), 1482-1501. DOI: 10.1093/bjc/azw093. \& Vera-Gray, F. (2017). "I Want To Be Able To Walk The Street Without Fear": Transforming Justice For Street Harassment. Feminist Legal Studies, 25(2), 203-227. DOI : 10.1007/s10691-017-93503-3.

Hermawati, I., \& Sofian, A. (2018). Kekerasan Seksual oleh Anak terhadap Anak. Jurnal Penelitian Kesejahteraan Sosial, 17(1), ISSN: 2528-0403.

Logan, L. S. (2015). Street Harassment: Current and Promising Avenues for Researchers and Activists. Sociology Compass, 9(3). DOI: https://doi.org/10.1111/soc4.12248.

Putri, L. J., \& Suardita, I. K. (2019). Tinjauan Yuridis Terhadap Perbuatan Catcalling (Pelecehan Verbal) Di Indonesia. Kertha Wicara, Retrieved from: https:// ojs.unud.ac.id/index.php/kerthawicara/article/view/47598.

Supanto, S. (2004). Pelecehan Seksual Sebagai Kekerasan Gender: Antisipasi Hukum Pidana. Mimbar: Jumal Sosial dan Pembangunan,20(3), 288-310, DOI: https://doi.org/10.29313/mimbar.v20i3.371.

Tesis atau Disertasi

Baja, Nico L. (2017). “Witwiw, Hi Miss!" Bastos Ba O Hindi: Catcalling Between Men and Women in Imus City, Cavite. Cavite State University.

O'Leary, Coleen. (2016). Catcalling As A "Double Edged Sword": Midwestern Women. Their Experiences and The Implications Of Men's Catcalling Behaviors, Illinois State University.

\section{Online/World Wide Web}

11 th Principle: Consent!. (tanpa tahun). Rape Culture Pyramid. Available at: https://www.11thprincipleconsent.org/consent-propaganda/rape-culturepyramid/. (Diakses pada tanggal 15 April 2019).

Dewan Perwakilan Rakyat Repubulik Indonesia. (2017). Naskah Akademik Rancangan Undang-Undang Tentang Penghapusan Kekerasan Seksual. Available at: http://www.dpr.go.id/doksileg/proses1/RJ1-20170307-091105-5895.pdf, (Diakses tanggal 9 April 2019).

Dharni, Arman. (2017). Dedi Mulyadi, Catcalling dan Ragam Pelecehan Perempuan. Available from https://tirto.id/dedi-mulyadi-catcalling-dan-ragam-pelecehanperempuan-b6cC. (Diakses pada 9 April 2019).

Komnas Perempuan. Catatan Kererasan Terhadap Perempuan Tahun 2017. Available from https://www.komnasperempuan.go.id/file/pdf_file/2018/Publikasi/Catatan \%20Tahunan\%20Kekerasan\%20Terhadap\%20Perempuan\%202018.pdf. (Diakses tanggal 20 Maret 2019).

Munti, Ratna Batara. (2001). Kekerasan Seksual: Mitos dan Realitas. Available at: https://www.hukumonline.com/berita/baca/hol2472/kekerasan-seksualmitos-dan-realitas. (Diakses tanggal 9 April 2019).

Stop Street Harassment. "Statistics - The Prevalence of Street Harassment". Available from http://www.stopstreetharassment.org/resources/statistics/statisticsacademic-studies/. (Diakses tanggal 15 Maret 2019). 